\title{
INDUSTRY-WISE LEGAL EXPENSES ANALYSIS OF INDIAN COMPANIES
}

\author{
Hemant Kushwaha \\ Research Scholar, School of Business Shri Mata Vaishno Devi University, \\ Jammu \& Kashmir, India.
}

\begin{abstract}
This study analyzes the industry-wise legal expense pattern and its relation with total expense and sales for the period of 2009-2010 to 2018-2019. Also, identify a group of industries having high legal expenses. Data of 1851 sample companies are collected from the CMIE ProwessIQ database, which is segregated into different industries groups from A to $U$ as per NIC Industries Code 2008. The analysis is done through ratio analysis and trend analysis. Results found that legal expenses show an increasing trend in growth and few industries have higher legal expenses than average legal expenses. Also, some legal requirements are common but some may differ from industry to industry they operate.
\end{abstract}

Key words: Legal expenses, Legal needs, Industries, Growth rate.

Cite this Article: Hemant Kushwaha, Industry-Wise Legal Expenses Analysis of Indian Companies, International Journal of Management, 11(12), 2020, pp. 18331840.

http://iaeme.com/Home/issue/IJM?Volume=11\&Issue=12

\section{INTRODUCTION}

Indian legal environment is changing very fast and the legal expenses of companies are also increasing in a few years. The fee paid for legal services is known as a legal fee. Fees can be paid in a different form to the legal service providers such as an hourly, statutory, flat, courtapproved, mixture of the continent, and hourly fee. (The free dictionary, 2020). The legal expense includes cost of postage, court fee, processing fee, witness fee, courier, filing fees, expert and consultancy fee, etc. (Attorney-Client Match, 2020)

The legal requirement of industries varies from industry to industry, though it shares some common legal needs such as filing tax returns and company law compliances, etc. Every Industry working environment and process of operation are different, even product and issues dealing with differs. Like labor used in manufacturing is different than labor working in hospitals and telecommunication companies. They have different skills and demand for different facilities. Even the case and its terminology are different from industry to industry. Around more than half of total legal expenses are from sector pharmaceuticals, banking \& finance, refineries, information technology infrastructure in the FY 2015 (Yoosef, 2015). Indian 
listed companies' legal expense increases in the last five years due to the introduction of regulation laws (Vyas \& Kadam, 2019) such as the law on insurance, companies Act 2013.

Below is the table, there are few industries discussed with their legal requirement, industries namely manufacturing, banking and securities, energy and resource, Insurance, Real estate, Technology, media \& telecommunications. The legal need of the companies in an industry differs from other operating in the other industry

Table 1. Industry-wise legal need

\begin{tabular}{|c|c|c|}
\hline Industry & Legal Requirements & Companies \\
\hline $\begin{array}{l}\text { Banking } \\
\text { and } \\
\text { Securities }\end{array}$ & $\begin{array}{l}\text { Assistance for loan transactional, loan work out/restructuring finance } \\
\text { deals, NPL deals, assistance in getting licensing and regulatory } \\
\text { compliance, financial and credit institutions, Mergers and acquisitions } \\
\text { of licensed entities, Reorganization of licensed entities via intra-group } \\
\text { mergers/spin-off's, assistance for Pre/Post IPO, Public offerings, } \\
\text { Market abuse cases, Securities law compliance, Stock option plans. }\end{array}$ & $\begin{array}{l}\text { Banking and securities } \\
\text { include company dealing } \\
\text { with financial services, } \\
\text { cross-border, complex } \\
\text { multidisciplinary } \\
\text { approach }\end{array}$ \\
\hline $\begin{array}{l}y \text { and } \\
\text { ces }\end{array}$ & $\begin{array}{l}\text { M\&A advice, drafting relevant M\&A documents, Closing, and post- } \\
\text { closing activity, M\&A advice concerning possible damages, } \\
\text { Assistance in corporate structuring and financing, Commercial } \\
\text { agreements, Regulatory market study activities, Cross-functional } \\
\text { capabilities, Employment, and benefits law. Advise companies in } \\
\text { determination of utility rates, antitrust issues, service dispute litigation, } \\
\text { and compliance with federal and state utility regulations, Rate } \\
\text { compliance, compliance related to environmental protection agency's } \\
\text { act. }\end{array}$ & $\begin{array}{l}\text { Energy and resources } \\
\text { include company dealing } \\
\text { in oil, gas, power, water, } \\
\text { mining, shipping, and } \\
\text { ports. }\end{array}$ \\
\hline su & $\begin{array}{l}\text { National and international reorganizations, legal, regulatory } \\
\text { compliance, and review of insurance contracts. }\end{array}$ & \\
\hline te & $\begin{array}{l}\text { Real estate transactions and due } \\
\text { and asset management, Construc } \\
\text { and planning, Dispute resolution }\end{array}$ & $\begin{array}{l}\text { property companies, } \\
\text { tconstruction, and } \\
\text { engineering companies }\end{array}$ \\
\hline $\begin{array}{l}\text { ology } \\
\text { ia \& } \\
\text { nmun } \\
\text { s }\end{array}$ & $\begin{array}{l}\text { Intellectual Property/Intellectual Capital; royalty recognition, Cross- } \\
\text { border mergers, and acquisitions, Commercial contracting; licensing, } \\
\text { Corporate restructuring, PE, joint venture, Intangibles Management, } \\
\text { (unfair) competition, Outsourcing (IT and BPO), Business Model } \\
\text { Optimization, Supply chain management, Compliance, Regulatory, } \\
\text { public sector, Litigation, ADR and Tax Controversy support, } \\
\text { Employment and Benefits, Distribution, Insurance. }\end{array}$ & $\begin{array}{lr}\text { Technology } & \text { related } \\
\text { company } & \text { including } \\
\text { hardware, } & \text { software, } \\
\text { internet, } & \text { technology } \\
\text { services } & \end{array}$ \\
\hline & $\begin{array}{l}\text { intellectual-property rights-drafting and filing patents, copyrights, and } \\
\text { trademarks, patent infringement disputes and an increase in new } \\
\text { product developments, federal and state product standards, inspection } \\
\text { and compliance issues, approval, and fulfilling the requirements and } \\
\text { conditions of food and drug administrations. }\end{array}$ & $\begin{array}{l}\text { Companies included } \\
\text { which indulge in } \\
\text { manufacturing of any }\end{array}$ \\
\hline assistance & $\begin{array}{l}\text { Compliance guidelines related to public policy, insurance coverage, } \\
\text { advice on regulatory changes, compliance guidelines related to public } \\
\text { policy, insurance coverage, patient protection acts, reimbursement } \\
\text { rates for Medicare and Medicaid patients, compensation and } \\
\text { reimbursement rates, compliance, and implementation of health care } \\
\text { acts. }\end{array}$ & \\
\hline
\end{tabular}

Source: adapted from $w w w 2$.deloitte.com and $w w w . i b i s w o r l d . c o m$

The government has made different laws, policies, and regulations for different industries. As from the above table, health care companies have to comply with guidelines issued by the medical association and implement as per the health care act, and banking companies need to adhere to rules for NPA. 


\section{NEED OF THE STUDY}

Recently, increasing legal expenses in past few year and fast changing legal environment. Now, companies act has been revised, new laws, rules and regulations has been introduced such as GST to lowering the fraud and promoting digital and transparent environment. The study investigates industry-wise legal expenses during the period 2010 to 2019 . To get better understanding of legal expenses and its portion in sales and legal expenses.

\section{OBJECTIVES}

- To analyze the industry-wise legal expense of Indian companies and identify the industry spending high legal expenses.

- To analyze the proportion of legal expense with sales, total expense.

\section{METHODOLOGY}

For assessing the potential demand for business legal expenses in India, first, it is essential to understand its business industry and legal environment in the industry. For achieving this objective, the author extracted companies' data for the period of the year 2010 to 2019 of CMIE ProwessIQ 1.95. There are 51021 companies' data available in the prowess, but complete data is not available for all years for the variable of legal charges, sales, and total expense. It was difficult to sort and fill in missing information one by one, and the pattern of missing data varied from company to company. So, it was easy and convenient to filter the companies from having missing data. There were only 1851 companies left. After that, using the NIC code (National Industrial Classification), data have been classified into different industries from division A to U (Table 2).

Table 2. Industry classification

\begin{tabular}{|l|l|l|l|}
\hline Division & \multicolumn{1}{|c|}{ Name } & Division & \multicolumn{1}{c|}{ Name } \\
\hline A & Agriculture, forestry, and fishing & J & Information and communication \\
\hline B & Mining and quarrying & K & Financial and insurance activities \\
\hline C & Manufacturing & M & $\begin{array}{l}\text { Professional, scientific, and } \\
\text { technical activities }\end{array}$ \\
\hline D & $\begin{array}{l}\text { Electricity, gas, steam, and air } \\
\text { conditioning supply }\end{array}$ & N & $\begin{array}{l}\text { Administrative and support service } \\
\text { activities }\end{array}$ \\
\hline F & Construction & O & $\begin{array}{l}\text { Public administration and defense; } \\
\text { compulsory social security }\end{array}$ \\
\hline G & $\begin{array}{l}\text { Wholesale and retail trade; repair of } \\
\text { motor vehicles and motorcycles }\end{array}$ & P & Education \\
\hline H & Transportation and storage & Q & $\begin{array}{l}\text { Human health and social work } \\
\text { activities }\end{array}$ \\
\hline I & $\begin{array}{l}\text { Accommodation and Foodservice } \\
\text { activities }\end{array}$ & R & Arts, entertainment, and recreation \\
\hline
\end{tabular}

Source: www.mospi.nic.in

\section{ANALYSIS AND INTERPRETATIONS}

The study uses cross-tabulation to show results of the trend of legal expense. It used 10-years average Legal expense, sales to analyze the industry's performance over 10 years. The study also uses the ratio of legal expense to sales and legal charge to total expense to identify the industry-wise effect of legal expense effect on sales and total expenses. 
Table 3 Industry-wise 10-year average

\begin{tabular}{|c|c|c|c|c|c|c|}
\hline Division & $\begin{array}{c}\text { No. of } \\
\text { companies }\end{array}$ & \% & $\begin{array}{c}\text { 10 Yr. Avg. } \\
\text { Total } \\
\text { Expenses } \\
\text { (million) }\end{array}$ & $\begin{array}{c}\text { 10 Yr. Avg. } \\
\text { sales } \\
\text { (million) }\end{array}$ & $\begin{array}{c}\text { 10 Yr. Avg. } \\
\text { Legal } \\
\text { Expenses } \\
\text { (million) }\end{array}$ & $\begin{array}{c}\text { Average legal } \\
\text { expenses per } \\
\text { company }\end{array}$ \\
\hline A & 72 & $3.89 \%$ & 86710.4 & 83461.2 & 281.94 & 3.92 \\
\hline B & 29 & $1.57 \%$ & 337609 & 352513 & 145.98 & 5.03 \\
\hline C & 883 & $47.70 \%$ & 88830.8 & 88916.8 & 475.54 & 0.54 \\
\hline D & 37 & $2.00 \%$ & 611763 & 577793 & 718.55 & 19.42 \\
\hline F & 115 & $6.21 \%$ & 94766.8 & 90148.8 & 419.59 & 3.65 \\
\hline G & 230 & $12.43 \%$ & 72415.9 & 69372.8 & 217.44 & 0.95 \\
\hline H & 63 & $3.40 \%$ & 170889 & 163828 & 399.64 & 6.34 \\
\hline I & 42 & $2.27 \%$ & 14230.7 & 12614.4 & 158.54 & 3.77 \\
\hline J & 128 & $6.92 \%$ & 19025.1 & 170254 & 1386.13 & 10.83 \\
\hline K & 106 & $5.73 \%$ & 44269.2 & 4181.87 & 280.48 & 2.65 \\
\hline M & 44 & $2.38 \%$ & 30787.9 & 31057.6 & 243.22 & 5.53 \\
\hline N & 54 & $2.92 \%$ & 13886.2 & 13647.8 & 154.3 & 2.86 \\
\hline O & 1 & $0.05 \%$ & 7507.9 & 10012.5 & 91.1 & 91.1 \\
\hline P & 18 & $0.97 \%$ & 16361.4 & 15180.9 & 134.16 & 7.45 \\
\hline Q & 21 & $1.13 \%$ & 44457.9 & 42271.9 & 465.89 & 22.19 \\
\hline R & 8 & $0.43 \%$ & 12177.3 & 11236 & 119.08 & 14.88 \\
\hline Total & 1851 & $100.00 \%$ & & & & 3.07 \\
\hline Source & & & & & \\
\hline
\end{tabular}

Source: Compiled and calculated by the author

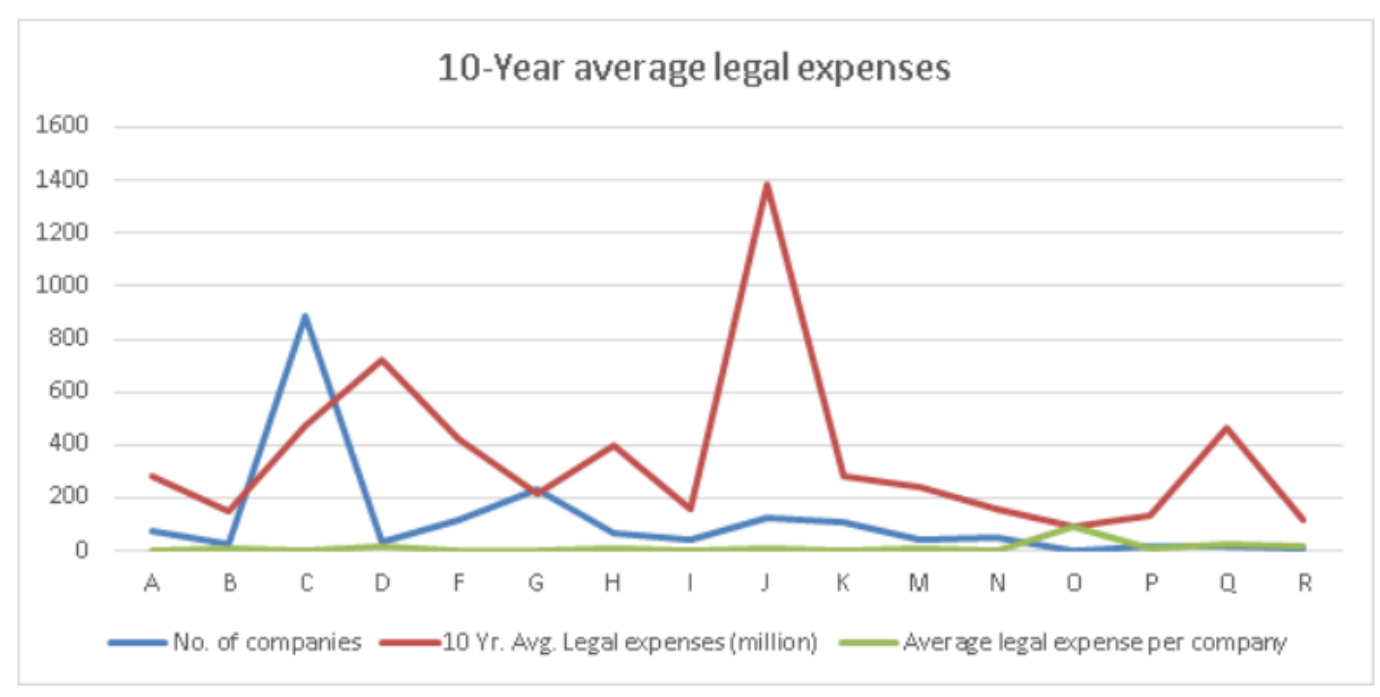

Figure 1. 10-year legal charges

In the above table 3, it can be observed that Division C: Manufacturing, which has 883 (47\%) of the total sample companies having total average legal expenses for ten years is 475.54 million, and it has the lowest average legal cost per company is Rs. 0.54 million. Division G: Wholesale and retail trade; repair of motor vehicles and motorcycles having Rs. 0.95 million.

Division $\mathrm{J}$ has the highest 10-year average legal expenses (Rs. 1386.13 million), followed by division D (Rs 718.55 million), which has the highest total expense (Rs. 611763 million) and highest 10-year average sales in division D (Rs. 577793 million) (Figure 1). 
Hemant Kushwaha

Table 4. Legal charge growth rate

\begin{tabular}{|c|c|c|c|c|}
\hline Division & $\begin{array}{c}\text { YOY Growth Rate of legal } \\
\text { expenses (10 Yr. Avg.) (\%) }\end{array}$ & $\begin{array}{c}\text { CAGR } \\
\text { (in \%) }\end{array}$ & $\begin{array}{c}\text { Legal expenses } \\
\text { to sales (\%) }\end{array}$ & $\begin{array}{c}\text { Legal expenses to } \\
\text { total expenses (\%) }\end{array}$ \\
\hline $\mathrm{A}$ & $9 \%$ & $8 \%$ & $0.34 \%$ & $0.33 \%$ \\
\hline $\mathrm{B}$ & $12 \%$ & $11 \%$ & $0.04 \%$ & $0.04 \%$ \\
\hline $\mathrm{C}$ & $14 \%$ & $13 \%$ & $0.53 \%$ & $0.54 \%$ \\
\hline $\mathrm{D}$ & $16 \%$ & $15 \%$ & $0.12 \%$ & $0.12 \%$ \\
\hline $\mathrm{F}$ & $11 \%$ & $11 \%$ & $0.47 \%$ & $0.44 \%$ \\
\hline $\mathrm{G}$ & $14 \%$ & $13 \%$ & $0.31 \%$ & $0.30 \%$ \\
\hline $\mathrm{H}$ & $16 \%$ & $16 \%$ & $0.24 \%$ & $0.23 \%$ \\
\hline $\mathrm{I}$ & $7 \%$ & $6 \%$ & $1.26 \%$ & $1.11 \%$ \\
\hline $\mathrm{J}$ & $14 \%$ & $13 \%$ & $0.81 \%$ & $7.29 \%$ \\
\hline $\mathrm{K}$ & $8 \%$ & $7 \%$ & $6.71 \%$ & $0.63 \%$ \\
\hline $\mathrm{M}$ & $19 \%$ & $18 \%$ & $0.78 \%$ & $0.79 \%$ \\
\hline $\mathrm{N}$ & $17 \%$ & $14 \%$ & $1.13 \%$ & $1.11 \%$ \\
\hline $\mathrm{O}$ & $77 \%$ & $35 \%$ & $0.91 \%$ & $1.21 \%$ \\
\hline $\mathrm{P}$ & $21 \%$ & $18 \%$ & $0.88 \%$ & $0.82 \%$ \\
\hline $\mathrm{Q}$ & $23 \%$ & $22 \%$ & $1.10 \%$ & $1.05 \%$ \\
\hline $\mathrm{R}$ & $83 \%$ & $28 \%$ & $1.06 \%$ & $0.98 \%$ \\
\hline
\end{tabular}

Calculated by the Author

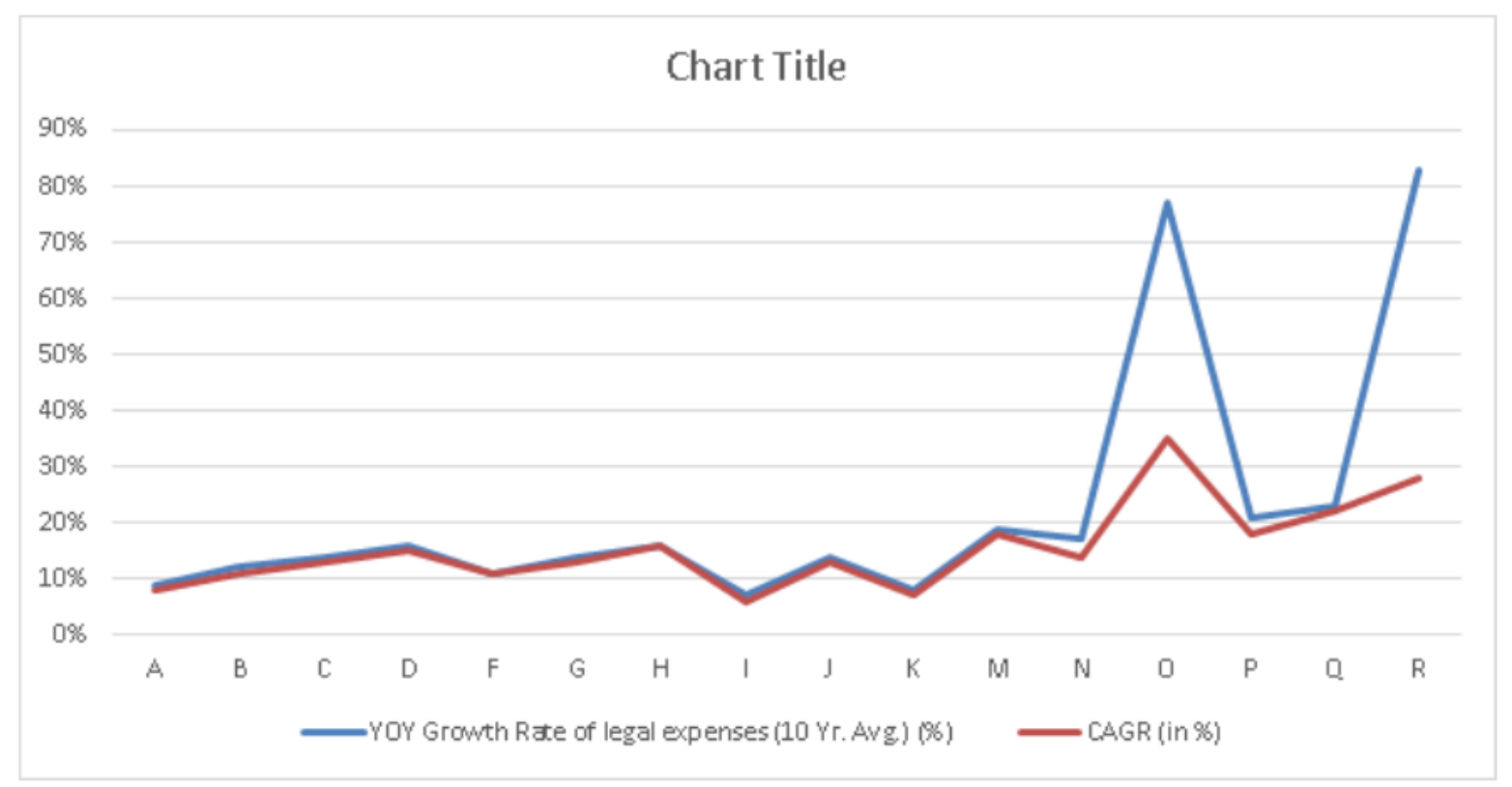

Figure 2 Legal expense growth rate

Table 4 shows that there is an increase in the year-on-year growth rate of legal expenses for a ten-year average ranging from $7 \%$ to $83 \%$. Highest YOY (Year on Year) growth rate is $83 \%$ for division $\mathrm{R}$ and the lowest for division $\mathrm{I}$ is $7 \%$. Where Division $\mathrm{R}$ has $28 \% \mathrm{CAGR}$ (Compounded Average Growth Rate) and division I have 6\% (Figure 2). 
Industry-Wise Legal Expenses Analysis of Indian Companies

Chart Title

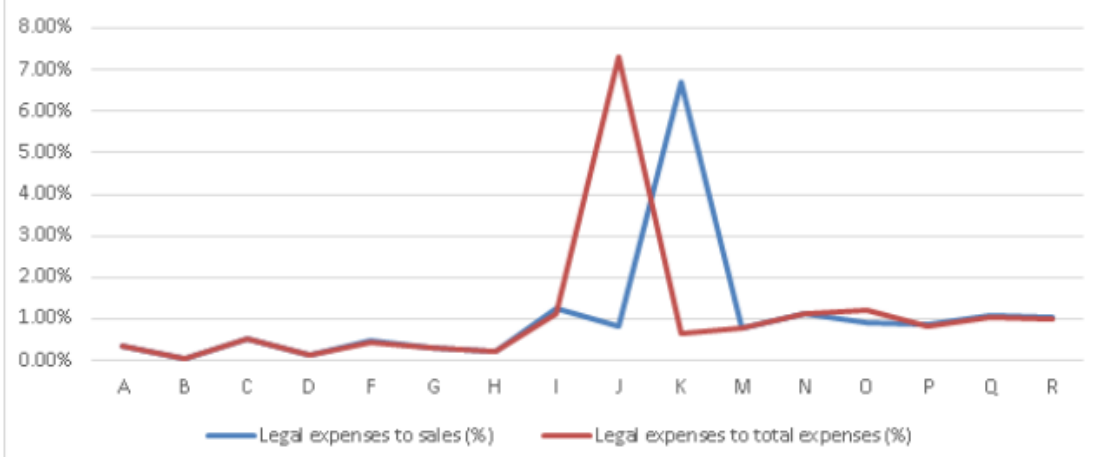

Figure 3. Legal expense growth rate

Legal expenses to sales ratio show a portion of legal charges in total sales. Division $\mathrm{K}$ is $6.71 \%$ and the minimum is in Division B is $0.04 \%$. The legal expense to total expense ratio shows a portion of legal expense in total expense. It varies from 0.045 to $7.29 \%$, division B is $0.04 \%$ to division $\mathrm{J}$ is $7.29 \%$ (Figure 3 ).

Table 5 Industry-wise legal expenses (Rupees in millions)

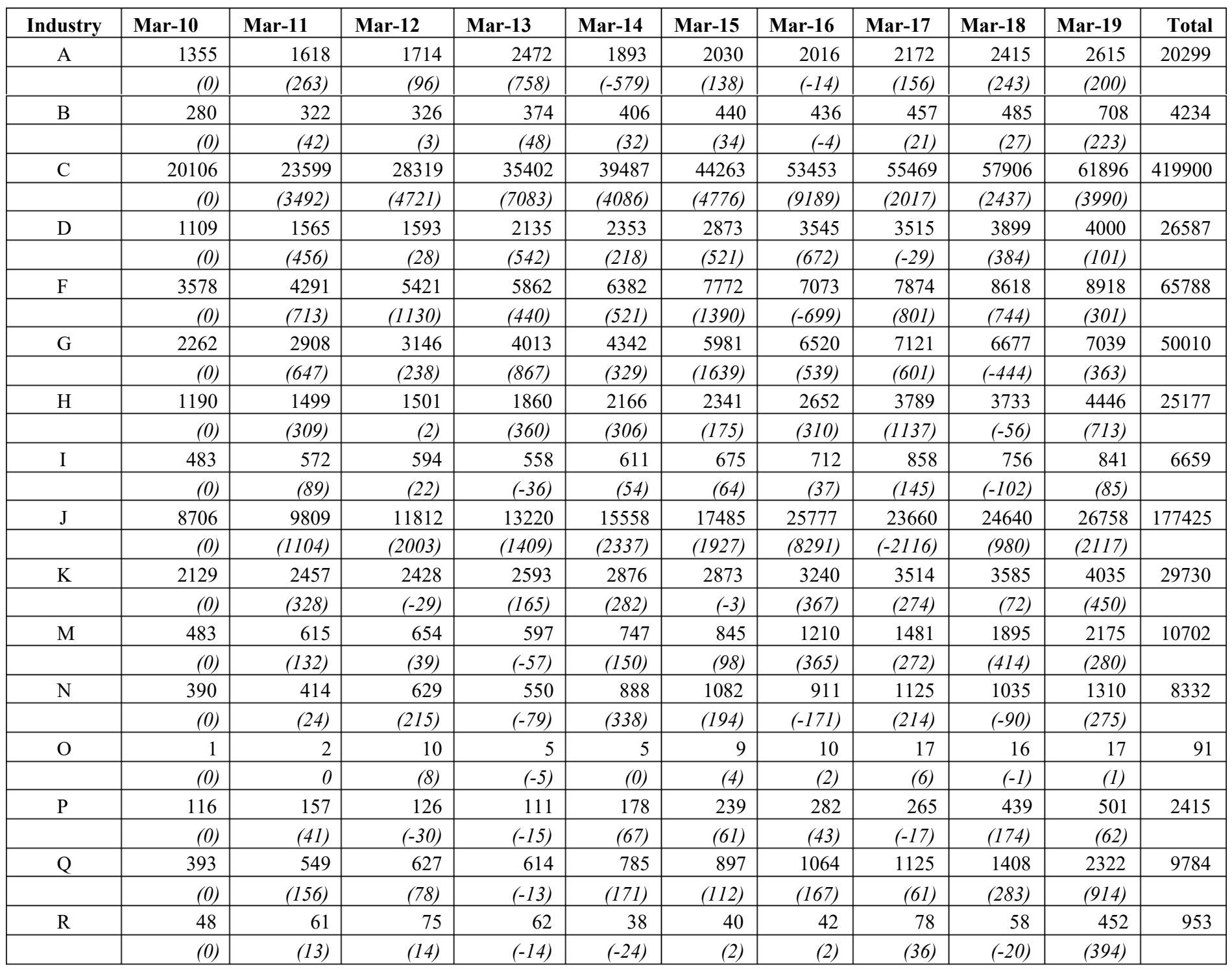


Source: Author's calculation

Note: Figures inside the brackets represents a yearly change from the previous year.

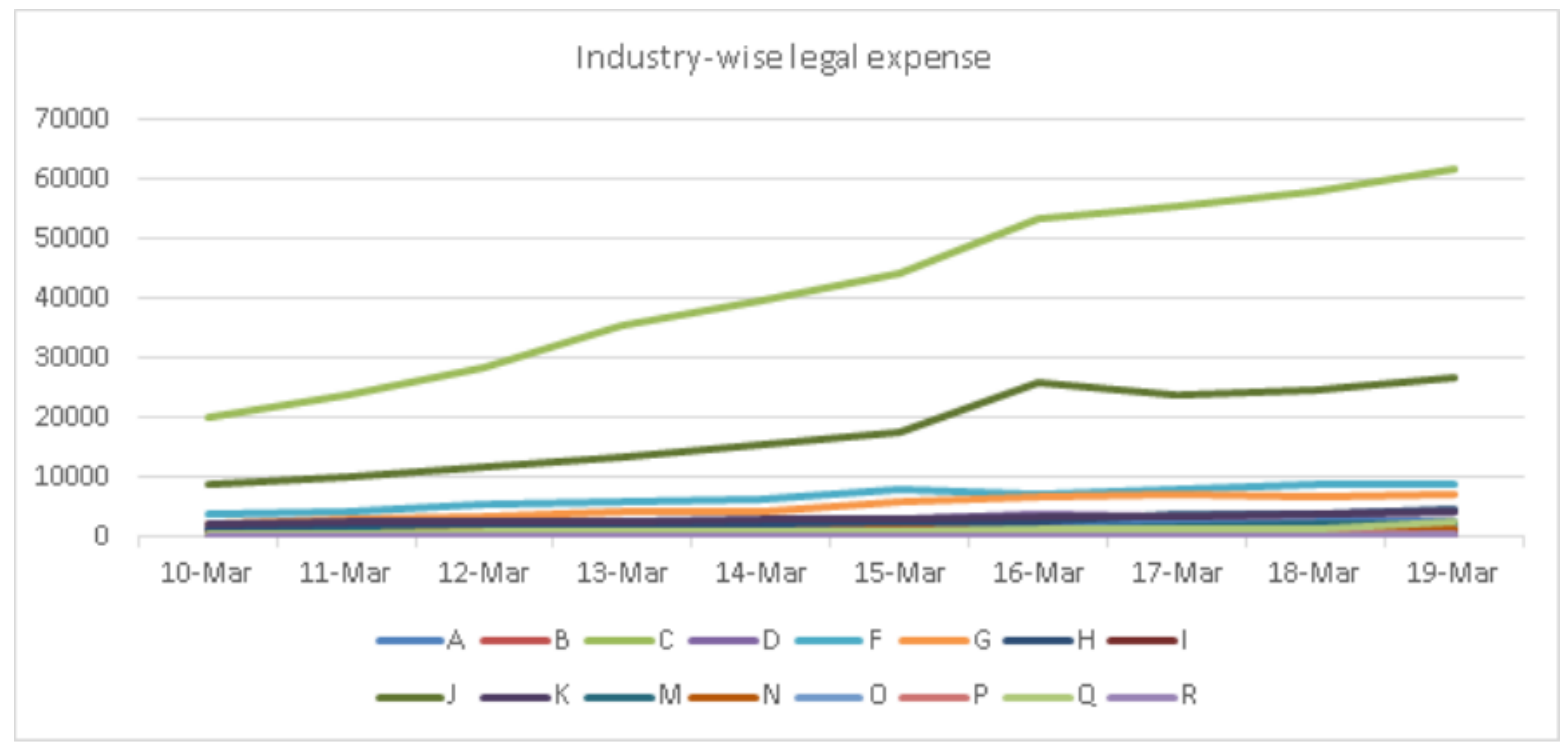

Figure 4. Industry-wise legal expense

Legal expense shows an increasing trend over the period from 2010 to 2019 (Table 4), Division $\mathrm{C}$ shows the highest legal expenses in division $\mathrm{C}$, followed by division $\mathrm{D}$ and division $\mathrm{J}$ (Figure. 4). There is more than a $100 \%$ increase in legal expense in comparison from 2010.

\section{FINDINGS}

- Around half of the sample companies (47.7\%) fall under division C: Manufacturing industry. Which is having Rs. 475 million 10-years legal expense and Rs. 0.54 million legal expense per company legal expenses. Though it has 10 -year average sales is around Rs. 88916.8 million.

- Division J: Information and communication incurred highest 10-year legal expense is Rs. 1386.13 million, followed by Division D: is Rs. 718.55 million.

- Division O has the highest legal expense per company (Rs. 91.1), but it can be ignored as it has only one company of the sample under this division. Division Q spends approx. Rs. 22.19 million per company.

- In terms of growth in legal expense over ten years, Division $\mathrm{R}$ is having the highest YOY growth rate of $83 \%$ and $28 \%$ CAGR. Followed by division $\mathrm{Q}$ and $\mathrm{P}$ having YOY growth rates are $23 \%$ and $21 \%$, whereas the CAGR for division $\mathrm{Q}$ is $22 \%$ and division $\mathrm{P}$ has $18 \%$.

- Legal charges to sales is $1.04 \%$ on an average for all industries ranging from $0.04 \%$ to $6.71 \%$. Division K: has the highest effect of legal expense on sales i.e., $6.71 \%$. Legal charges to total expense ratio are highest in division $\mathrm{J}$ i.e., $7.29 \%$, and its range is from $0.04 \%$ to $7.29 \%$. Division B has the lowest legal expenses to sales and legal expenses to total expenses.

- Legal expense shows an increasing trend from 2010 to 2019 for almost every industry. Division $\mathrm{C}$ show the highest increase in legal expense over the period

- Some legal needs of companies are common and some legal needs vary from industry to industry. 


\section{CONCLUSION}

Based on results and findings, it can be concluded that legal expenses show increasing trends for almost all companies. Further, legal requirements and legal expenses of companies vary from industry to industry due to the nature of business and the environment in which they operate. Companies working in industries such as Information and communication, Electricity, gas, steam, and air conditioning supply, manufacturing have high legal expenses. The study shows manufacturing is an important industry for the Indian economy and also legal expenses are high. Legal expenses have a higher portion of the total expense and sales in the industries such as financial and insurance activities and information and communication. This study creates a better understanding of legal expenses. However, industry-wise analysis of legal expense is new. Further research is required to find the reasons for varying legal expenses.

\section{REFERENCE}

[1] Attorney client match, 2020. How legal fees different than expenses. https://www.attorneyclientmatch.com/how-are-legal-fees-different-than-expenses.html

[2] Deloitte, 2019. Deloitte Legal Industries. https://www2.deloitte.com/bg/en/pages/legal/articles/deloitte-legal-industries.html

[3] Palmer, T. and Morea, S., 2017. Top industries with rising demand for legal services. IBIS World. https://www.ibisworld.com/industry-insider/spotlight-reports/top-industries-withrising-demand-for-legal-services

[4] The free Dictionary, 2020. https://www.thefreedictionary.com/legal+fee

[5] Vyas, V. \& Kadam, S., 2019. India Inc spent 14\% more on legal fees in FY19. The Economic Times. https://economictimes.indiatimes.com/news/company/corporate-trends.

[6] Yoosef, K.P., 2015. Legal, professional costs outpace net revenues for corporate India. Financial Express. https://www.financialexpress.com/market/legal-professional-costs-outpacenet-revenues-for-corporate-india/144703/ 